\title{
US to increase public participation in regulation of DNA research
}

SignIFICANr changes in procedures for regulating research involving recombinant DNA techniyues are soon to be announced by the US National Institutes of Health (NIH). In parıcular, there will be greater public participation in both local biosafety committees and the NIH's Kecombinant DNA Advisory Committee; and tighter provisions decermining tesponsibility for ensuring that reguatory guidelines are observed.

Other changes expected to be announced are expansion of the scope of the present guidelines to cover recombinant DNA research carried out in institutions receiving support for such research from any federal agency (not just NIH); stricter rules about the public notice required to alter the guidelines; and increased provision for taking "risk assessment" considerations into account when deciding whether certain types of experiment should be exempt from the guidelines.

A revised version of the guidelines, which were first iniroduced by $\mathrm{NIH}$ in July 1976, were delivered to Secretary for Health, Mr Joseph Califano, at the end of last week. If he approves the changes, as is expected, then the new guidelines will be published in the Federal Register within a few weeks.

Proposed revisions to the guidelines were issued by Dr Donald Fredrickson, director of NIH, earlier this year. In particular, Dr Fredrickson has recommended lowering the levels of containment required for certain types of experiments (and to exempt other experiments from the guidelines completely) in the light of scientific evidence that has accumulated since concern over the possible social impact of recombinant DNA research was first raised five years ago.

Most of the suggested revisions to the scientific aspects of the guidelines are expected to be retained in the final version, apart from a few deletions from the list of exemptions. The major changes will occur in Part IV of the guidelines, that which covers "roles and responsibilities".

Much of the impetus for this change has come directly from $\mathrm{Mr}$ Califano, responding on the one hand to pressures from Congress-which is still threatening to introduce legislation to make up for any deficiencies it perceives in the guidelines-and on the other to public interest and environmental groups, which have been consistently critical of what they see as attempts to retain decision-making within the scientific community.
When NIH's proposed revisions were published, $\mathrm{Mr}$ Califano added an introduction specifically requesting comments on the proposed mechanisms for administering and revising the guidelines. Many such comments were aired at a public meeting held in Washingion in September before a departmental review committee established by $\mathrm{Mr}$ Califano under the chairmanship of $\mathrm{Mr}$ Peter Libassi, chief counsel of the Depariment of Health, Education and Welfare.

According to sources in Washington, the major impact of the review committee's intervention and its study of the various comments and criticisms received, will involve aspects of public participation in the regulatory process, as well as channels of responsibility and accountability.

In his proposed revisions to the guidelines, for example, Dr Fredrickson had suggested that considerable authority for the conduct of recombinant DNA experiments be devolved from NIH to local biosafety committees; and that, in addition to including those with expertise in the relevant fields of science and public policy, at least one member of such a committee "shall not be affiliated to the institution."

Critics, such as Friends of the Earth and the Environmental Defense Fund, argued that this did not go far enough in involving the public in the regulatory process, in particular since the wording still allowed the external appointment to be made by the institution. The final version is expected to say that at leas $i$ two members-or $20 \%$ of the total-should be appointed from outside, for example from environmental groups or local or state safety bodies.

Furthermore, membership of the Recombinant DNA Advisory Committee, another target of criticism, is to be increased from 14 to 20; the number of "public interest" representatives, is expected to be increased from two to six.

Additional changes to NIH's suggestions in the final version of the guidelines include clearly stated procedures for the director of NIH to adopt if it is proposed to make changes in the guidelines, specifying which changes need to be offered for public comment, which require advance notice, and which can merely be announced. Provision is also expected to be included for NIH to be able to remove the authority delegated to a local biosafety committee if it considers the committee's performance to be unsatisfactory.
One target of criticism in the suggested revisions was the proposal that, although certain types of experiments would continue to be prohibited, case-by-case exceptions would be allowed for experiments for which there were "compelling social or scientific reasons", provided that weight was given to "scientific and social benefits and to potential risks".

This language is now to be tightened up, so that the general standard for all such decisions will be an assessment that the experiment in question poses "no serious risk".

Two final points relate to the commercial aspects of recombinant DNA research. Firstly, the advisory committee is to be asked to consider what ground rules should apply to experiments involving more than 10 litres of culture containing altered genes.

All such experiments-not merely those involving "harmful products," as at present-would be prohibited, but still subject to waiver by the director of NIH; in commenting on this ban, the pharmaceutical company Eli Lilley told Dr Fredrickson that the necessity for such experiments was "imminent".

Secondly, reflecting a concern that a "voluntary" approach to regulating experiments in private industry suggested by NIH is likely to prove inadequate, the Food and Drug Administration is to consider whether similar guidelines should be applied directly to the pharmaceutical industry.

Many of the expected changes are likely to be welcomed by public interest and environmental groups, since they go some way towards meeting the criticisms of the guidelines on which such groups have been concentrating in recent months. "Any movement towards more responsible mechanisms for operating the guidelines is a step in the right direction," Dr Jonathan King, professor of biology at Massachusetts Institutes of Technology said last week.

Officials at NIH are said to be less happy, fearing that they are being pushed into a more regulatory role than many would wish, and are losing some of their flexibility to manouevre. Publication of the revised guidelines is thought to have been delayed by negotiations between NIH and DHEW.

Many of the changes answer criticisms given by Senator Adlai Stevenson, in a letter to $\mathrm{Mr}$ Califano last month, as reasons why he considered legislation still necessary. Mr Stevenson is said to be happier with the final version and the prospect of legislation may be receding.

David Dickson 